\title{
Tetracycline Resistant Genes in E. coli Isolated from UTI and Diarrhea Patients in Zaria, Nigeria
}

\author{
Igwe $\mathrm{JC}^{1^{*}}$, Musa $\mathrm{A}^{2}$, Olayinka $\mathrm{BO}^{3}$, Ehnimidu $\mathrm{JO}^{3}$ and Onaolapo $\mathrm{JA}^{3}$
}

${ }^{1}$ Department of Medical Biotechnology, National Biotechnology Development Agency, Abuja, Nigeria

${ }^{2}$ Department of Water Sanitation and Hygiene, Dutse Local Government, Jigawa State, Nigeria

${ }^{3}$ Department of Pharmaceutics and Pharmaceutical Microbiology, Ahmadu Bello University, Zaria, Nigeria

*Corresponding author: Igwe JC, Department of Medical Biotechnology, National Biotechnology Development Agency, Abuja, Nigeria, Tel: +234-8069430222; E-mail: igwejames42@yahoo.com

Received date: October 07, 2015; Accepted date: December 23, 2015; Published date: December 30, 2015

Copyright: () 2015 Igwe JC, et al. This is an open-access article distributed under the terms of the Creative Commons Attribution License, which permits unrestricted use, distribution, and reproduction in any medium, provided the original author and source are credited.

\begin{abstract}
Tetracycline (TC) is one of the widely used antibiotics for the treatment of infections with significant therapeutic effect due to its broad spectrum. But due to the emergence of high percentages of tetracycline resistance and the recent reoccurrence of multidrug resistance isolates in clinical settings, its use in hospitals have drastically reduced. This study evaluates the percentage of TC resistant in clinical isolates of $E$. coli from UTI and diarrhea patients in Zaria, Nigeria. Out of the $86 \mathrm{E}$. coli isolates collected from 4 hospitals for the period of 6 months (April-September, 2014), 68.6\% (59) were observed to be resistant to TC using both disc diffusion and MIC (range of $\geq 4 \mu \mathrm{g} / \mathrm{ml}$ ) methods. The antibiotic susceptibility profile of the isolates showed that the isolates had varied antibiotic resistant profile to the 14 antibiotics tested. Significant percentage $(35.6 \%(21))$ of the isolates also exhibited simultaneous resistance to Ciprofloxacin, Gentamicin and Amoxicillin. The isolates were also observed to have high MARI, and there molecular analysis showed that $95 \%$ (20) of the MDR isolates had TetA gene while $90.5 \%$ (19) had TetB gene. Our results showed that there is a correlation between phenotypic TC resistance and genomic TetA and TetB carriage in E. coli isolates from UTI and diarrhea patients in Zaria, Nigeria.
\end{abstract}

Keywords: Tetracycline resistance; E. col; UTI and Diarrhea; Multidrug resistance

\section{Introduction}

Multidrug resistance (MDR) among pathogenic Escherichia coli is one of the leading causes of increased mortality and morbidity, which has contributed majorly to public health problems in both developed and developing countries. Pathogenic Escherichia coli develop MDR due to their capacity to acquire different genetic markers by horizontal gene transfer especially conjugation [1]. Resistance to Glycylcyclines (Tetracycline) has been associated with multimeric antiporter proteins (Tet proteins A, B, C, L and M), embedded in the bacterial inner membrane, which in exchange for a proton, catalyze the outward transport of tetracycline- $\mathrm{Mg}^{2+}$ complexes from the cytosol. Tet proteins actively efflux antibiotics out of the microbial cell membrane and protect the ribosome DNA, which lead to multidrug resistance $[2,3]$. Tetracycline enters bacterial cells by passive diffusion across the outer membrane through porin channels, which are composed of the OmpF protein. Transport of the antibiotic across the cytoplasmic membrane and into the cytoplasm requires $\mathrm{pH}$ or electropotential gradients [4]. These Tets genes have been transferred to a large variety of Gram-negative bacteria (Salmonella enterica [5], Acinetobacter baumannii [6], Escherichia coli [7], and P. aeruginosa [8]) and Gram positive bacteria (Lactobacillus spp. [9]) due to horizontal gene transfer. Two mutations in the largest cytoplasmic loop of the efflux pump, which resulted from a double frame shift in codons 201, 202 and 203 have been reported to increase the MIC of Tigecycline in Escherichia coli [10], contributing largely to antibiotics resistance. These mechanisms have incapacitated broad spectrum antibiotics such as Tetracycline, Tigecycline and minocycline [11]. Isolates that coded for Tetracycline resistance genes have been reported in food sample (tet $(\mathrm{M})$ and tet $(\mathrm{L})$ ); rivers, lakes, seawater, catfish, cows and clinical settings (tetA, tetB, tetC,) [3,11-13]. This has indeed generated a public health concern, due to limited number of antibiotics produced by pharmaceutical industries and low innovative research and limitations associated with clinical trials, which influence the availability of antibiotics for clinical use. Hence, surveillance to monitor the development and prevalence of resistance mechanisms against developed antibiotics is necessary. This study therefore evaluates the level of Tetracycline resistance in Escherichia coli among UTI and diarrhea patients in Zaria, Nigeria.

\section{Methodology}

\section{Sample collection}

One hundred and thirty two presumptive clinical isolates of $E$. coli were randomly collected from 4 hospitals within Zaria metropolis for the period of 6 months (April-September, 2014). Using MicrobactTM $12 \mathrm{E}$ Gram negative identification kit, 87 of the isolates were confirmed as E. coli.

\section{Antibiotic susceptibility testing}

The antibiotic susceptibility profile of the identified $E$. coli isolates to Tetracycline and some other 14 selected antibiotics were carried out using Kirby-Bauer [14] disc diffusion method and their corresponding results were interpreted using CLSI [15]. Multiple antibiotic resistance index and classification into different subclass of multidrug resistance 
Citation: Igwe JC, Musa A, Olayinka BO, Ehnimidu JO, Onaolapo JA (2015) Tetracycline Resistant Genes in E. coli Isolated from UTI and Diarrhea Patients in Zaria, Nigeria. Clin Microbiol 4: 225. doi:10.4172/2327-5073.1000225

Page 2 of 7

were carried out using the methods described by Paul et al. [16] and Magiorakos et al. [17] respectively.

\section{Molecular analysis}

The DNA of MDR E. coli that were resistant to Tetracycline from UTI and Diarrhea patients in Zaria, Nigeria were extracted using Zymo Research DNA extraction kit with Lot No: ZRC182717 while the PCR was carried out at the Department of Bioscience, International Institute of Tropical, Agriculture, Ibadan using the primers for tetA (Forward: GTAATTCTGAGCACTGTCGC and Reverse: CTGCCTGGACAACATTGCTT ) of 937 base pair and tetB (Forward: CTCAGTATTCCAAGCCTTTG and Reverse: CTAAGCACTTGTCTCCTGTT) of 416 base pair for the amplification of the corresponding genes.

\section{Results and Discussion}

Occurrence rate of Escherichia coli from UTI and Diarrhea patients within Zaria, Nigeria for the period of 6 months (April-September,
2014), were carried out in 4 hospitals, and 132 presumptive Escherichia coli were recovered. Significant numbers of the isolates [65.2\% (86)] were confirmed to be Escherichia coli active Escherichia coli $(62.2 \%$ (82) and slow lactose fermenting Escherichia coli (inactive) [3\% (4)]\}, while $34.8 \%$ (46) were other Enterobacteriacea (Table 1). Sixty eight point six percent $\{68.6 \%(59)\}$ of the isolates were resistant to Tetracycline while $31.4 \%$ (27) were not resistant to it. The antibiotic susceptibility profile of the Tetracycline resistant isolates showed that Imipinem (1.2\%), Amikacin (5.1\%), Ceftriaxone (27.1\%), Nitrofurantoin (28.8\%), Azetronam (42.4\%) and Gentamicin (49.2\%) were the most effective antibiotics for the treatment of Tetracycline resistant Escherichia coli in Zaria, Nigeria. The isolates were mostly resistant to antibiotics such as Amoxicillin (93.2\%), Cefpodoxime (88.1\%), Cefotaxime (84.7\%), Cefpirome (64.4\%), and Sulphamethonidazole-Trimethroprim (61\%) while mid resistance was observed against Flouroquinolones (Ciprofloxacin (54.2\%) and Ofloxacin (54.2\%)) (Table 2). Significant percentages (35.6\% (21)) of the isolates were also observed to show resistance against Gentamicin, Ciprofloxacin and Amoxicillin respectively (Table 2).

\begin{tabular}{|c|c|c|c|c|c|c|}
\hline \multirow{2}{*}{ S/N } & Hospitals Sampled (n=4) & \multicolumn{2}{|c|}{ Diarrhea (S) } & \multicolumn{2}{|c|}{ UTI (U) } \\
\hline & & Isolates collected & E. coli (\%) & Isolates collected & E. coli (\%) & \\
\hline 1 & ABUTH & 15 & $11(73.3)$ & 28 & $21(75)$ & $43(32.6)$ \\
\hline 2 & ABUSB & 12 & $7(58.3)$ & 22 & $15(68.2)$ & $34(25.7)$ \\
\hline 3 & SLAH & 10 & $8(80)$ & 19 & $9(47.4)$ & $29(22)$ \\
\hline 4 & HGSGH & 9 & $6(66.7)$ & 17 & $9(52.9)$ & $26(19.7)$ \\
\hline & Total & 46 & $32(69.6)$ & 86 & $54(62.8)$ & $132(100)$ \\
\hline
\end{tabular}

S/N: Serial Number; S: Stool sample of diarrhea patients; U: Urine sample of UTI patients; ABUTH: Ahmadu Bello University Teaching Hospital, Shika; ABUSB: Ahmadu Bello University Sick Bay; SLAH: St. Luke Anglican Hospital, Wusasa; HGSGH: Hajiya Gambo Sawaba General Hospital, Kofan-Gayan

Table 1: Occurrence rate of $E$. coli in diarrhea and urinary tract infections in Zaria, Nigeria. The result below showed the percentages of $E$. coli from diarrhea and UTI in each hospital sampled in Zaria, Nigeria.

\begin{tabular}{|c|c|c|c|c|c|c|c|c|}
\hline$S / N$ & $\begin{array}{l}\text { Isolates } \\
\text { Codes }\end{array}$ & Antibiotic S Resistance Pattern & $\begin{array}{c}\text { NA } \\
\text { R }\end{array}$ & $\begin{array}{l}\text { Tet. MIC } \\
(\mu \mathrm{g} / \mathrm{ml})\end{array}$ & $\begin{array}{l}\text { Class of Antibiotics } \\
\text { Resistance }\end{array}$ & LOR & $\begin{array}{c}\text { GR } \\
T\end{array}$ & $\begin{array}{c}\text { MAR } \\
I\end{array}$ \\
\hline 1 & THU1 & $\begin{array}{c}\text { OFX, ATM, CN, CPD, CRO, CPO, CTX, SXT, C, } \\
\text { AML }\end{array}$ & 11 & 128 & $\begin{array}{l}\text { FLU, MON, AMIN, CEPH, } \\
\text { MISC, PEN }\end{array}$ & XDR & 6 & 0.8 \\
\hline 2 & THU10 & $\begin{array}{l}\text { OFX, ATM, CN, CIP, CRO, CPD, CPO, CTX, } \\
\text { SXT,F, AML }\end{array}$ & 11 & 128 & $\begin{array}{l}\text { FLU, AMIN, MON, CEPH, } \\
\text { MISC, PEN }\end{array}$ & $\mathrm{XDR}$ & 6 & 0.8 \\
\hline 3 & THU25 & $\begin{array}{l}\text { OFX, ATM, CN, CIP, CRO, CPD, CPO, CTX, } \\
\text { SXT, C, AML, F }\end{array}$ & 12 & 256 & $\begin{array}{l}\text { FLU, MON, AMIN, CEPH, } \\
\text { MISC, PEN }\end{array}$ & XDR & 6 & 0.9 \\
\hline 4 & THU27 & $\begin{array}{c}\text { OFX, CN, CIP, CRO, CPD, CPO, CTX, SXT, } \\
\text { AML, F }\end{array}$ & 10 & 128 & FLU, AMIN, CEPH, MISC, PEN & XDR & 5 & 0.8 \\
\hline 5 & THS12 & $\begin{array}{c}\text { CN, OFX, ATM, CIP, CRO, CPD, CPO, CTX, } \\
\text { SXT, C, AML }\end{array}$ & 11 & 128 & $\begin{array}{l}\text { FLU, MON, AMIN, CEPH, } \\
\text { MISC, PEN }\end{array}$ & XDR & 6 & 0.8 \\
\hline 6 & THS1 & OFX, CN, CIP, CPD, CPO, CTX, SXT, C, AML & 9 & 64 & FLU, AMIN, CEPH, MISC, PEN & XDR & 5 & 0.7 \\
\hline 7 & THS8 & $\begin{array}{c}\text { CN, OFX, ATM, CIP, CRO, CPD, CPO, CTX, } \\
\text { SXT, C, AML }\end{array}$ & 11 & 128 & $\begin{array}{l}\text { FLU, MON, AMIN, CEPH, } \\
\text { MISC, PEN }\end{array}$ & XDR & 6 & 0.8 \\
\hline 8 & THS15 & CN, OFX, CIP, CPD, CPO, CTX, SXT, AML & 8 & 64 & FLU, AMIN, CEPH, MISC, PEN & XDR & 5 & 0.6 \\
\hline
\end{tabular}


Citation: Igwe JC, Musa A, Olayinka BO, Ehnimidu JO, Onaolapo JA (2015) Tetracycline Resistant Genes in E. coli Isolated from UTI and Diarrhea Patients in Zaria, Nigeria. Clin Microbiol 4: 225. doi:10.4172/2327-5073.1000225

Page 3 of 7

\begin{tabular}{|c|c|c|c|c|c|c|c|c|}
\hline 9 & SBS1 & CN, OFX, CIP, CPD, CPO, CTX, SXT, C, AML & 9 & 64 & FLU, AMIN, CEPH, MISC, PEN & XDR & 5 & 0.7 \\
\hline 10 & SBS7 & $\begin{array}{l}\mathrm{CN}, \mathrm{OFX}, \mathrm{CIP}, \mathrm{CPD}, \mathrm{CPO}, \mathrm{CTX}, \mathrm{SXT}, \mathrm{C}, \mathrm{AML} \text {, } \\
\mathrm{IPM}\end{array}$ & 10 & 128 & $\begin{array}{l}\text { FLU, AMIN, CEPH, MISC, } \\
\text { PEN, CAB }\end{array}$ & $\mathrm{XDR}$ & 6 & 0.8 \\
\hline 11 & SBS11 & CN, OFX, CIP, CPO, CTX, SXT, AML & 7 & 64 & FLU, AMIN, CEPH, MISC, PEN & XDR & 5 & 0.5 \\
\hline 12 & SBU2 & CN, OFX, CIP, CPD, CPO, CTX, SXT, AML & 8 & 64 & FLU, AMIN, CEPH, MISC, PEN & XDR & 5 & 0.6 \\
\hline 13 & SBU8 & CN, OFX, CIP, CPO, CTX, SXT, AML & 7 & 64 & FLU, AMIN, CEPH, MISC, PEN & $\mathrm{XDR}$ & 5 & 0.5 \\
\hline 14 & SBU12 & $\begin{array}{c}\text { CN, ATM, OFX, CIP, CRO, CPD, CPO, CTX, } \\
\text { SXT, C, AML, F }\end{array}$ & 12 & 256 & $\begin{array}{l}\text { FLU, MON, AMIN, CEPH, } \\
\text { MISC, PEN }\end{array}$ & $\mathrm{XDR}$ & 6 & 0.9 \\
\hline 15 & SBU13 & $\begin{array}{c}\text { CN, ATM, OFX, CIP, CRO, CPD, CPO, CTX, } \\
\text { SXT, C, AML }\end{array}$ & 11 & 128 & $\begin{array}{l}\text { FLU, MON, AMIN, CEPH, } \\
\text { MISC, PEN }\end{array}$ & XDR & 6 & 0.8 \\
\hline 16 & SBU15 & CN, OFX, CIP, CPD, CPO, CTX, SXT, C, AML & 9 & 64 & FLU, AMIN, CEPH, MISC, PEN & XDR & 5 & 0.7 \\
\hline 17 & SBU16 & $\begin{array}{l}\text { CN, ATM, OFX, CIP, CPD, CPO, CTX, SXT, C, } \\
\text { AML }\end{array}$ & 10 & 128 & $\begin{array}{l}\text { FLU, MON, AMIN, CEPH, } \\
\text { MISC, PEN }\end{array}$ & XDR & 6 & 0.8 \\
\hline 18 & SBU17 & CN, OFX, CIP, CPD, CPO, CTX, SXT, AML & 8 & 64 & FLU, AMIN, CEPH, MISC, PEN & $\mathrm{XDR}$ & 5 & 0.6 \\
\hline 19 & SBU20 & CN, OFX, CIP, CPD, CPO, SXT, C, AML & 8 & 64 & FLU, AMIN, CEPH, MISC, PEN & XDR & 5 & 0.6 \\
\hline 20 & SLS6 & OFX, CIP, CN, CRO, CPO, CTX, AML & 7 & 64 & FLU, AMIN, CEPH, PEN & $\begin{array}{c}\mathrm{MD} \\
\mathrm{R}\end{array}$ & 4 & 0.5 \\
\hline 21 & SLU3 & OFX, CIP, AK, F, SXT, CXT, AML & 8 & 64 & FLU, AMIN, CEPH, MISC, PEN & $\mathrm{XDR}$ & 5 & 0.6 \\
\hline 22 & HGS5 & CN, ATM, OFX, F, CPD, CPO, CTX, SXT, AML & 10 & 128 & $\begin{array}{l}\text { FLU, MON, AMIN, CEPH, } \\
\text { MISC, PEN }\end{array}$ & XDR & 6 & 0.8 \\
\hline 23 & HGS6 & CN, ATM, OFX, CIP, F, CPD, CTX, AML & 8 & 64 & $\begin{array}{l}\text { FLU, MON, AMIN, CEPH, } \\
\text { MISC, PEN }\end{array}$ & XDR & 6 & 0.6 \\
\hline 24 & HGU1 & CN, OFX, CIP, CPD, CPO, CTX, SXT, AML & 8 & 64 & FLU, AMIN, CEPH, MISC, PEN & XDR & 5 & 0.6 \\
\hline 25 & HGU16 & CN, ATM, OFX, CIP, CRO, CPD, CTX, C, AML & 9 & 64 & $\begin{array}{l}\text { FLU, MON, AMIN, CEPH, } \\
\text { MISC, PEN }\end{array}$ & XDR & 6 & 0.7 \\
\hline 26 & SBU22 & $\mathrm{CPD}, \mathrm{CPO}, \mathrm{AML}$ & 3 & 16 & CEPH, PEN & NIL & 2 & 0.2 \\
\hline 27 & SLS1 & CPO, CTX, SXT, AML & 4 & 16 & CEPH, MISC, PEN & $\begin{array}{c}\mathrm{MD} \\
\mathrm{R}\end{array}$ & 3 & 0.3 \\
\hline 28 & SLS2 & AML & 1 & 8 & $P$ & $\mathrm{NIL}$ & 1 & 0.1 \\
\hline 29 & SLS3 & CPD, CPO, CTX, SXT, AML & 5 & 32 & CEPH, MISC, PEN & $\begin{array}{c}\mathrm{MD} \\
\mathrm{R}\end{array}$ & 3 & 0.4 \\
\hline 30 & SLS5 & OFX, CIP, CN, CRO, CPO, CTX, C & 7 & 64 & FLU, AMIN, CEPH, MISC, PEN & XDR & 5 & 0.5 \\
\hline 31 & SLS8 & AK, CRO, ATM, CPO, CXT & 5 & 32 & MON, AMIN, CEPH & $\begin{array}{c}\mathrm{MD} \\
\mathrm{R}\end{array}$ & 3 & 0.4 \\
\hline 32 & SLS9 & CPO, CTX, AML & 3 & 16 & CEPH, PEN & NIL & 2 & 0.2 \\
\hline 33 & SLU2 & CPO, CTX, SXT, & 3 & 16 & CEPH, MISC & NIL & 2 & 0.2 \\
\hline 34 & SLU3 & OFX, CIP, AK, F, SXT, CXT, AML & 8 & 64 & FLU, AMIN, CEPH, MISC, PEN & XDR & 5 & 0.6 \\
\hline 35 & SLU4 & CPD, CPO, C, AML & 4 & 16 & CEPH, MISC, PEN & $\begin{array}{c}M D \\
R\end{array}$ & 3 & 0.3 \\
\hline 36 & SLU7 & CPD, CPO, ATM & 4 & 16 & CEPH, MON & NIL & 2 & 0.3 \\
\hline 37 & SLU8 & OFX, CIP, CPD, CPO, ATM, AML & 6 & 32 & FLU, MON, CEPH, PEN & $\begin{array}{c}\mathrm{MD} \\
\mathrm{R}\end{array}$ & 4 & 0.5 \\
\hline 38 & HGS2 & $\mathrm{CN}, \mathrm{F}, \mathrm{CPD}, \mathrm{CPO}, \mathrm{SXT}, \mathrm{AML}$ & 6 & 32 & AMIN, CEPH, MISC, PEN & $\begin{array}{c}\mathrm{MD} \\
\mathrm{R}\end{array}$ & 4 & 0.5 \\
\hline
\end{tabular}


Citation: Igwe JC, Musa A, Olayinka BO, Ehnimidu JO, Onaolapo JA (2015) Tetracycline Resistant Genes in E. coli Isolated from UTI and Diarrhea Patients in Zaria, Nigeria. Clin Microbiol 4: 225. doi:10.4172/2327-5073.1000225

Page 4 of 7

\begin{tabular}{|c|c|c|c|c|c|c|c|c|}
\hline 39 & HGS3 & ATM, CPD, CTX, AML & 4 & 16 & CEPH, MON, PEN & $\begin{array}{c}\mathrm{MD} \\
\mathrm{R}\end{array}$ & 3 & 0.3 \\
\hline 40 & HGS4 & ATM, CPD, CPO, CTX, AML & 3 & 16 & CEPH, MON, PEN & $\begin{array}{c}\mathrm{MD} \\
\mathrm{R}\end{array}$ & 3 & 0.2 \\
\hline 41 & HGU4 & $\mathrm{F}, \mathrm{CPO}, \mathrm{SXT}, \mathrm{AML}$ & 4 & 16 & CEPH, MISC, PEN & $\begin{array}{c}\mathrm{MD} \\
\mathrm{R}\end{array}$ & 3 & 0.3 \\
\hline 42 & HGU6 & $\mathrm{C}, \mathrm{CXT}, \mathrm{AML}$ & 3 & 16 & CEPH, AMIN, PEN & $\begin{array}{c}\mathrm{MD} \\
\mathrm{R}\end{array}$ & 3 & 0.2 \\
\hline 43 & HGU7 & ATM, F, CPD, CPO, CTX, SXT, AML & 7 & 64 & MON, CEPH, MISC, PEN & $\begin{array}{c}\mathrm{MD} \\
\mathrm{R}\end{array}$ & 4 & 0.5 \\
\hline 45 & HGU9 & F, CRO, CPD, CPO, CTX, AML & 6 & 64 & MON, CEPH, MISC, PEN & $\begin{array}{c}\mathrm{MD} \\
\mathrm{R}\end{array}$ & 4 & 0.3 \\
\hline 46 & HGU14 & ATM, F, CPD, CPO, CTX, AML & 6 & 64 & MON, CEPH, MISC, PEN & $\begin{array}{c}\mathrm{MD} \\
\mathrm{R}\end{array}$ & 4 & 0.5 \\
\hline 47 & THU3 & ATM, CPO, CTX, SXT, AML & 5 & 64 & CEPH, MISC, PEN & $\begin{array}{c}\mathrm{MD} \\
\mathrm{R}\end{array}$ & 3 & 0.5 \\
\hline 48 & THU5 & CPO, CTX, SXT, C, AML & 5 & 64 & MON, CEPH, MISC, PEN & $\begin{array}{c}\mathrm{MD} \\
\mathrm{R}\end{array}$ & 4 & 0.4 \\
\hline 49 & THU6 & ATM, CRO, CPO, CTX, C, AML & 6 & 64 & MON, CEPH, MISC, PEN & $\begin{array}{c}\mathrm{MD} \\
\mathrm{R}\end{array}$ & 4 & 0.4 \\
\hline 50 & THU7 & OFX, CIP, CPD, CPO, CTX, SXT, C, AML & 8 & 64 & FLU, CEPH, MISC, PEN & $\begin{array}{c}\mathrm{MD} \\
\mathrm{R}\end{array}$ & 4 & 0.5 \\
\hline 51 & THU8 & OFX, ATM, CIP, CPD, CPO, CTX, AML & 7 & 64 & FLU, MON, CEPH, PEN & $\begin{array}{c}\mathrm{MD} \\
\mathrm{R}\end{array}$ & 4 & 0.6 \\
\hline 52 & THU9 & CPD, CPO, CTX, AML & 4 & 16 & CEPH, PEN & NIL & 2 & 0.5 \\
\hline 53 & THU13 & OFX, ATM, CIP, CRO, CPD, CPO, CTX, C, AML & 9 & 64 & FLU, MON, CEPH, MISC, PEN & XDR & 5 & 0.3 \\
\hline 54 & THU14 & ATM, CPO, CTX, C, AML, F & 6 & 32 & MON, CEPH, MISC, PEN & $\begin{array}{c}\mathrm{MD} \\
\mathrm{R}\end{array}$ & 4 & 0.7 \\
\hline 55 & THU17 & $\mathrm{CPO}, \mathrm{CXT}, \mathrm{F}, \mathrm{AML}$ & 4 & 16 & CEPH, MISC, PEN & $\begin{array}{c}\mathrm{MD} \\
\mathrm{R}\end{array}$ & 3 & 0.5 \\
\hline 56 & THU18 & CPO, CTX, SXT, C, AML & 5 & 32 & CEPH, MISC, PEN & $\begin{array}{c}\mathrm{MD} \\
\mathrm{R}\end{array}$ & 3 & 0.3 \\
\hline 57 & THU19 & $\begin{array}{l}\text { OFX, ATM, CIP, CRO, CPD, CPO, CTX, SXT, } \\
\text { AML, F }\end{array}$ & 10 & 128 & FLU, AMIN, CEPH, MISC, PEN & XDR & 5 & 0.4 \\
\hline 58 & THU20 & CPO, CTX, SXT, C, AML & 7 & 64 & FLU, AMIN, CEPH, PEN & $\begin{array}{c}\mathrm{MD} \\
\mathrm{R}\end{array}$ & 4 & 0.8 \\
\hline 59 & THU21 & ATM, CN, CPD, CPO, CTX, AML & 6 & 32 & MON, AMIN, CEPH, PEN & $\begin{array}{c}\mathrm{MD} \\
\mathrm{R}\end{array}$ & 4 & 0.5 \\
\hline & & & & & & & & 0.5 \\
\hline \multicolumn{9}{|c|}{$\begin{array}{l}\text { S/N: Serial Number; NAR: Number of Antibiotics Resistance; Tet. MIC: Tetracycline Minimum Inhibitory Concentration; GRT: Number of groups of antibiotics each } \\
\text { isolate of E. coli is resistant to; FLU: Fluoroquinolone; MON: Monobactam; AMIN: Aminoglycoside; CEPH: Cephalosporin; MISC: Miscellaneous antibiotics; CAB: } \\
\text { Carbapenems; PEN: Penicillin; AK: Amikacin; OFX: Ofloxacin; F: Nitrofurantoin; ATM: Aztreonam; CN: Gentamicin; CIP: Ciprofloxacin; CPD: Cefpodoxime; CRO: } \\
\text { Ceftriaxone; CPO: Cefpirome; CTX: Ceftaxime; SXT: Sulphamethonidazole-Trimethroprim; C: Chloramphenicol; IPM: Imipenem; AML: Amoxicillin; MDR: Multidrug- } \\
\text { resistant; XDR: Extensively drug-resistant; NIL: Neither MDR nor XDR; MDR: Resistance to at least } 4 \text { groups of antibiotics; XDR: Resistance to } 5 \text { and above groups of } \\
\text { antibiotics tested; PDR: Non-susceptible to all antimicrobial agents listed. PDR was not considered because not all the antibiotics contained in the proposal of } \\
\text { Magiorakos et al. [18] are prescribed for infections associated with E. coli in A.B.U Teaching Hospital Shika, Zaria }\end{array}$} \\
\hline
\end{tabular}

Table 2: Antibiotics susceptibility profile and pattern of Tetracycline resistance E. coli from UTI and Diarrhea patients in Zaria, Nigeria. 


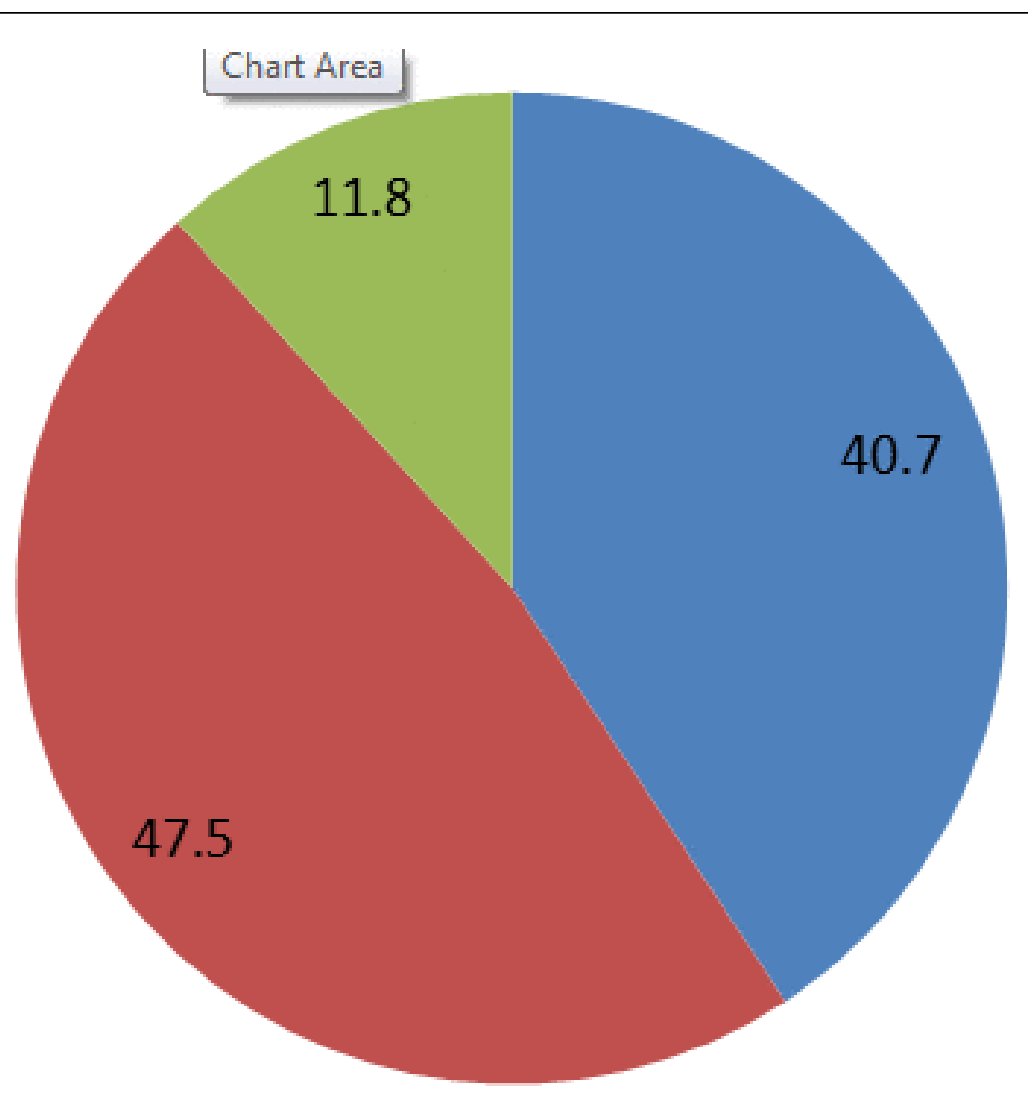

MDR XDR NIL

Figure 1: Percentage classification of E. coli isolates to different levels of antibiotics resistance. MDR: Multidrug-resistant; XDR: Extensively drug-resistant; NIL: Neither MDR nor XDR.

This study concur with the report of Okunola et al. [18] in Benin, and Rabasa et al. [19] in Marduguri who reported that E. coli associated infections are becoming highly untreatable due to antibiotics resistant, especially to the first line empirical antimicrobials such as Beta-lactames, Sulphanidazole/Trimethroprim, Nitrofuratoin and Nalidixic acid. The sensitivity of $E$. coli to Imipeneme, Amikacin, Ceftriazone, Gentamicin and Quinolones as observed in this study may be due to the fact that the Imipeneme and Amikacine are expensive and not commonly sold over the counter while Quinolones are rarely prescribed for children. The parenteral routes of Ceftriazone and Gentamicin reduce the abuse of these two antibiotics. Also concentration dependent bactericidal activity, extended post-antibiotic effect, and the possibility of reduced nephrotoxicity and ototoxicity also affect the recommendation of Gentamicin [20]. The susceptibility of $E$. coli to Ofloxacin and Ciprofloxacine observed in this study also concurs with the study of Kemebradikumo et al. [21] in Bayelsa, who reported $61.5 \%$ E. coli sensitivity to Ofloxacin and $75 \%$ for Ciprofloxacin. The slight variation in the sensitivity Quinolones observed in this study might be due to high prescription of Ciprofloxacine in this area compared to Ofloxacin. The Tetracycline resistant E. coli using disc diffusion method was also observed to have high resistant MIC values against Tetracycline (Table 2). Factors such as low patient compliance, menace of substandard antibiotics which is common in developing countries, self-medication, and potentially subtherapeutic prescription by health workers are some of the factors influencing multiple antibiotics resistance [22]. The MARI result showed that $23.7 \%$ (14) of the isolates have $\leq 0.3$ MARI while $76 \%$ (45) had MARI $\geq 0.4$ (Table 2). Classification of the isolates to different levels of resistance showed that $40.7 \%$ (24) of the isolates were multidrug resistance (resistance to 4 groups of antibiotics), $47.5 \%$ (28) were extensively drug-resistant (resistance to 5 or more than 5 antibiotics groups) while $11.8 \%$ (7) were neither MDR nor XDR (Figure 1). The high percentage of $E$. coli having MAR index $\geq 0.4$ (Tables 2) in this study, suggests that the isolates originated from a high risk source of contamination where antibiotics are often used [23], while the high percentage of XDR and MDR (Figure 1) might be an indication that a large proportion of the bacterial isolates have been pre-exposed to several antibiotics, and also, a combination of microbial characteristics such as selective pressure on antimicrobial usage, societal and technological changes that enhance the transmission of drug resistant organisms might be the cause of this high resistance [24]. To validate that the phenotypic resistance of the isolates to Teteracycline is also coded in the isolates genome, and to substantiate that efflux pumps mechanism which triggers the extrusion of structurally unrelated antibiotics from within the cells into the external environment and encourages multidrug resistance is involved in Tetracycline resistance mechanism, molecular analysis was carryout on the E. coli isolates (21) that were simultaneously resistant to Gentamicin, Amoxicillin and Ciprofloxacin using polymerase chain reaction and tet $A$ and tetB primers. The result showed that $95 \%$ (20) of the isolates of $E$. coli have tetA gene compared to $90.5 \%$ (19) tetB gene. This virulent genes were however higher than that observed by Nahid et al. [25], who reported $49 \%$ tet(A) and $51 \%$ tet(B) genes, both of which encode for efflux pumping mechanisms. The antibiotics 
Citation: Igwe JC, Musa A, Olayinka BO, Ehnimidu JO, Onaolapo JA (2015) Tetracycline Resistant Genes in E. coli Isolated from UTI and Diarrhea Patients in Zaria, Nigeria. Clin Microbiol 4: 225. doi:10.4172/2327-5073.1000225

Page 6 of 7

susceptibility pattern of the isolates also concur that tet(B)-positive strains appeared to be more virulent than tet(A)-positive strains [25]. This is due to the level of antibiotic resistance observed in carriers in this study. Documentary evidence have shown that strains that were tet(B)-or tet(A)-positive might also carry the genes for P fimbriae, iron-trapping compounds, hemolysin and aerobactin, respectively, more often than susceptible strains [25]. These acquirable virulent characteristics enable extra-intestinal pathogenic E. coli to adapt, colonize and persist in adhesion to urinary tract compared to other uropathogens [11,12] (Figures 2 and 3).



Figure 2: DNA extraction from tetracycline resistant E. coli isolated in Zaria, Nigeria.

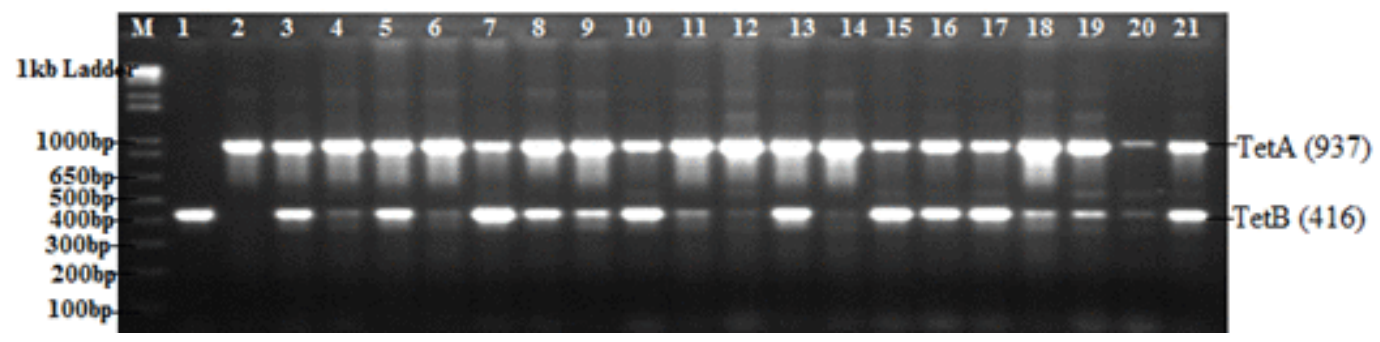

Figure 3: Multiplex Results of TetA and TetB Genes.

\section{Conclusion}

This study showed the presence of Tetracycline resistant $E$. coli in UTI and diarrhea patients in Zaria, Nigeria. Resistance to Tetracycline is highly associated with the presence of Tet proteins and isolates with Tet $\mathrm{B}$ protein were observed to be more resistant to those with TetA protein. Antibiotic surveillance to monitor the development and prevalence of resistance mechanisms against developed antibiotics is therefore necessary in this environ. Also awareness is important to encourage patient compliance, reduction in substandard antibiotics production in developing countries, reduced self-medication, and potentially sub-therapeutic prescription by health workers are some of the factors that should be curb to reduce multiple antibiotics resistance in Zaria, Nigeria.

\section{References}

1. Igwe JC, Onaolapo JA, Dauda EO, Oladipo HO (2013) Plasmid Conjugation in E. coli and Drug Resistance. Nig J Biotech 26: 41-49.

2. Stein GE, Craig WA (2006) Tigecycline: a critical analysis. Clin Infect Dis 43: 518-524.

3. Benacer D, Kwai LT, Haruo W, Savithri DP (2010) Characterization of drug resistance Salmonella enterica Serotype Typhimurium by antibiograms, plasmids, integrons, resistance genes and PFGE. J Microbiol Biotechnol 20: 1042-1052.

4. Weinmann P, Gossen M, Hillen W, Bujard H, Gatz C (1991) A chimeric transactivator allows tetracycline-responsive gene expression in whole plants. Plant J 5: 559-569.

5. Komano T, Yoshida T, Narahara K, Furuya N (2000) The transfer region of IncI1 plasmid R64: similarities between R64 tra and legionella icm/dot genes. Mol Microbiol 35: 1348-1359.

6. Martí S, Fernández-Cuenca F, Pascual A, Ribera A, Rodríguez-Baño J, et al. (2006) [Prevalence of the tetA and tetB genes as mechanisms of resistance to tetracycline and minocycline in Acinetobacter baumannii clinical isolates]. Enferm Infecc Microbiol Clin 24: 77-80.

7. Makino S, Asakura H, Obayashi T, Shirahata T, Ikeda T, et al. (1999) Molecular epidemiological study on tetracycline resistance R plasmids in enterohaemorrhagic Escherichia coliO157:H7. Epidemiol Infect 123: 25-30.

8. Xiong J, Hynes MF, Ye H, Chen H, Yang Y, et al. (2006) bla(IMP-9) and its association with large plasmids carried by Pseudomonas aeruginosa isolates from the People's Republic of China. Antimicrob Agents Chemother 50: 355-358.

9. Gevers D, Danielsen M, Huys G, Swings J (2003) Molecular characterization of tet $(\mathrm{M})$ genes in Lactobacillus isolates from different types of fermented dry sausage. Appl Environ Microbiol 69: 1270-1275. 
Citation: Igwe JC, Musa A, Olayinka BO, Ehnimidu JO, Onaolapo JA (2015) Tetracycline Resistant Genes in E. coli Isolated from UTI and Diarrhea Patients in Zaria, Nigeria. Clin Microbiol 4: 225. doi:10.4172/2327-5073.1000225

Page 7 of 7

10. Tuckman M, Petersen PJ, Projan SJ (2000) Mutations in the interdomain loop region of the tet $\mathrm{A}(\mathrm{A})$ tetracycline resistance gene increase efflux of minocycline and glycylcyclines. Microb Drug Resist 6: 277-282.

11. Akiyama T, Presedo J, Khan AA (2013) The tetA gene decreases tigecycline sensitivity of Salmonella enterica isolates. Int J Antimicrob Agents 42: 133-140.

12. Nawaz M, Khan AA, Khan S, Sung K, Kerdahi K, et al. (2009) Molecular Characterization of Tetracycline-Resistant Genes and Integrons from Avirulent Strains of Escherichia coli Isolated from Catfish. Journal of Food-borne Pathogens and Disease 6: 553-559.

13. Frazzon APG, Gama BA, Hermes V, Bierhals CG, Pereira RI, et al. (2009) Prevalence of antimicrobial resistance and molecular characterization of tetracycline resistance mediated by tetM and tetL genes in Enterococcus spp. isolated from food in Southern Brazil. World J Microbiol Biotechnol 26: 365-370.

14. Bauer AW, Kirby WM, Sherris JC, Turck M (1966) Antibiotic susceptibility testing by a standardized single disk method. Am J Clin Pathol 45: 493-496.

15. Clinical and Laboratory Standards Institute (CLSI) (2012) Performance standards for Antimicrobial Susceptibility Testing. CLSI document. Clinical and Laboratory Standards Institute, Pennsylvania, USA.

16. Paul S, Bezbaruah RL, Roy MK, Ghosh AC (1997) Multiple antibiotic resistance (MAR) index and its reversion in Pseudomonas aeruginosa. Lett Appl Microbiol 24: 169-171.

17. Magiorakos AP, Srinivasan A, Carey RB, Carmeli Y, Falagas ME, et al. (2012) Multidrug-resistant, extensively drug-resistant and pandrugresistant bacteria: an international expert proposal for interim standard definitions for acquired resistance. CMI 18: 268-281.
18. Okunola PO, Ibadin MO, Ofovwe GE, Ukoh G (2012) Co-existence of urinary tract infection and malaria among children under five years old: a report from Benin City, Nigeria. Saudi J Kidney Dis Transpl 23: 629-634.

19. Rabasa AI, Shattima D (2002) Urinary tract infection in severely malnourished children at the University of Maiduguri Teaching Hospital. J Trop Pediatr 48: 359-361.

20. Behm-Dillon DM (2000) Appropriate Use of Antibiotics: The Antibiotic Advisory Subcommittee and You.

21. Pondei K, Orutugu L, Pondei J (2012) Current microbial and culture sensitivity pattern of urinary tract infection in a private hospital setting in Bayelsa State, Nigeria. IRJM 3: 393-398.

22. Chukwu BF, Okafor HU, Ikefuna AN (2011) Asymptomatic bacteriuria in children with sickle cell anemia at The University of Nigeria teaching hospital, Enugu, South East, Nigeria. Ital J Pediatr 37: 45.

23. Christopher AF, Hora S, Ali Z (2013) Investigation of plasmid profile, antibiotic susceptibility pattern multiple antibiotic resistance index calculation of Escherichia coli isolates obtained from different human clinical specimens at tertiary care hospital in Bareilly-India. Annals of Tropical Medicine and Public Health 6: 285-289.

24. Orozova P, Chikova V, Kolarova V, Nenova R, Konovska M, et al. (2008) Antibiotic resistance of potentially pathogenic Aeromonas strains. Trakia Journal of Sciences 6: 71-78.

25. Karami N, Nowrouzian F, Adlerberth I, Wold AE (2006) Tetracycline resistance in Escherichia coli and persistence in the infantile colonic microbiota. Antimicrob Agents Chemother 50: 156-161. 